\title{
Penentuan Lingkungan Pengendapan Batubara Berdasarkan Karakteristik dan Maseral Batubara di PT X, Kabupaten Nunukan, Kalimantan Utara
}

\author{
Nurakhmi Qadaryati $^{1 *}$, Dendi Tantra Praditya ${ }^{1}$, Wahju Krisna Hidajat ${ }^{1}$, \\ Indriyani Martiningtyas ${ }^{2}$ \\ ${ }^{1}$ Departemen Teknik Geologi, Fakultas Teknik, Universitas Diponegoro \\ ${ }^{2}$ PT SUCOFINDO (Persero) Cabang Balikpapan, Graha Sucofindo, Jl. A. Yani no. 1, Balikpapan -76122
}

\begin{abstract}
Abstrak
Kabupaten Nunukan termasuk wilayah yang signifikan menyumbang cadangan batubara di Indonesia dengan cadangan hipotetik mencapai sepuluh juta ton. Salah satu data yang dibutuhkan dalam tahapan eksplorasi lanjut batubara adalah informasi lingkungan pengendapan. Penelitian ini bertujuan untuk menentukan lingkungan pengendapan batubara Miosen di Kabupaten Nunukan, Kalimantan Utara. Metode yang dilakukan dalam penelitian yaitu analisis petrografi mencakup analisis maseral dan mineral, pengukuran vitrinite reflectance, plotting Tissue Preservation Index (TPI) terhadap Gelification Index (GI). Komposisi batubara di daerah penelitian tersusun dari dominasi vitrinit (68\%$91 \%)$ juga dijumpai mineral pirit $(0,9 \%-6,6 \%)$. Berdasarkan hasil analisis, batubara di daerah penelitian adalah lignit $(\mathrm{Ro}=0,39 \%-0,44 \%)$. Plot Tissue Preservation Index (TPI) dan Gelification Index (GI) menunjukkan bahwa pada saat mengendapkan gambut, daerah penelitian berada pada lingkungan lower delta plain, lahan gambut wet forest swamp dan clastic marsh, serta pada kondisi lingkungan pengendapan telmatic dan limno-telmatic. Kehadiran pirit framboidal mengindikasikan formasi pembawa batubara mengalami reduksi sulfat, yang berasal dari lingkungan anoxic, dengan ion besi pada saat pembatubaraan.
\end{abstract}

Kata kunci : Maseral; Nunukan; Reflektansi Vitrinit; TPI-GI.

\begin{abstract}
Nunukan Regency, North Borneo, significantly contributes coal reserves in Indonesia with hypothetical reserves reaching ten million tons. One of the data required in the next stage of coal exploration is information of depositional environment. This study aims to determine the Miocene coal depositional environment in Nunukan Regency. The method used in this research are petrographic analysis including observation of minerals and minerals, measurement of vitrinite reflectance, plotting tissue preservation index (TPI) of Gelification Index (GI). The composition of coal in the study area composed of vitrinite dominance (68\% -91\%), pyrite minerals are also identified (0.9\% -6.6\%). Based on the analysis, coal in the study area is lignite $(R o=0.39 \%-0.44 \%)$. Tissue Preservation Index (TPI) and Gelification Index (GI) plot shows that the study area is in the lower delta plain environment, wet forest swamp and clastic marsh peatlands, and in the telmatic and limno-telmatic depositional environment during peat accumulation. The presence of ramboidal pyrite indicates the coal bearing formation experienced reduction of sulfates, from anoxic environment, with iron ions during coalification.
\end{abstract}

Keyword: Maceral; Nunukan; Vitrinite Reflectance; TPI-GI.

\section{PENDAHULUAN}

Indonesia memiliki sumberdaya batubara sebesar 166 miliar ton dan cadangan batubara di Indonesia sebanyak 37 miliar ton (Susilawati, 2018). Hal inilah yang menjadikan sektor pertambangan batubara menjadi salah satu penyumbang pemasukan negara yang cukup besar. Kegiatan pertambangan batubara di Indonesia paling banyak berada di Sumatera dan Kalimantan. Kabupaten Nunukan sendiri termasuk wilayah yang signifikan menyumbang cadangan batubara di Indonesia dengan cadangan hipotetik mencapai sepuluh juta ton (Triono, 2005).

Kualitas batubara pada dasarnya merupakan sebuah kesepakatan antara pihak peneliti dan pembeli (konsumen), karena kualitas batubara dilihat berdasarkan fungsinya. Kualitas dari sebuah batubara dipengaruhi oleh lingkungan

*) Korespondensi: nurakhmi@live.undip.ac.id 
batubara terendapkan, lingkungan tersebut akan menunjukkan komposisi penyusun batubara.

Batubara pada penelitian ini berasal dari Kabupaten Nunukan, Kalimantan Utara. Sedelinggam (2015) telah melakukan studi mengenai batubara di daerah penelitian dengan menggunakan data palinologi. Pada penelitian ini dilakukan penentuan lingkungan pengendapan batubara berdasarkan data maseral yang diplot pada diagram Tissue Preservation Index (TPI) dan Gelification Index (GI) (Lamberson, 1991).

\section{TINJAUAN PUSTAKA \\ Kondisi Geologi}

Kabupaten Nunukan berada di Provinsi Kalimantan Utara, wilayah ini dikelompokkan menjadi dua satuan morfologi, yaitu satuan perbukitan bergelombang sedang - terjal yang berada di sebelah utara dan satuan perbukitan bergelombang landai di bagian selatan (Wibisono dan Wawang, 2015). Secara regional Kabupaten Nunukan berada di Subcekungan Tidung yang merupakan bagian dari Cekungan Tarakan (Gambar 1). Cekungan Tarakan termasuk salah satu dari cekungan Tersier yang terdapat di timur continental

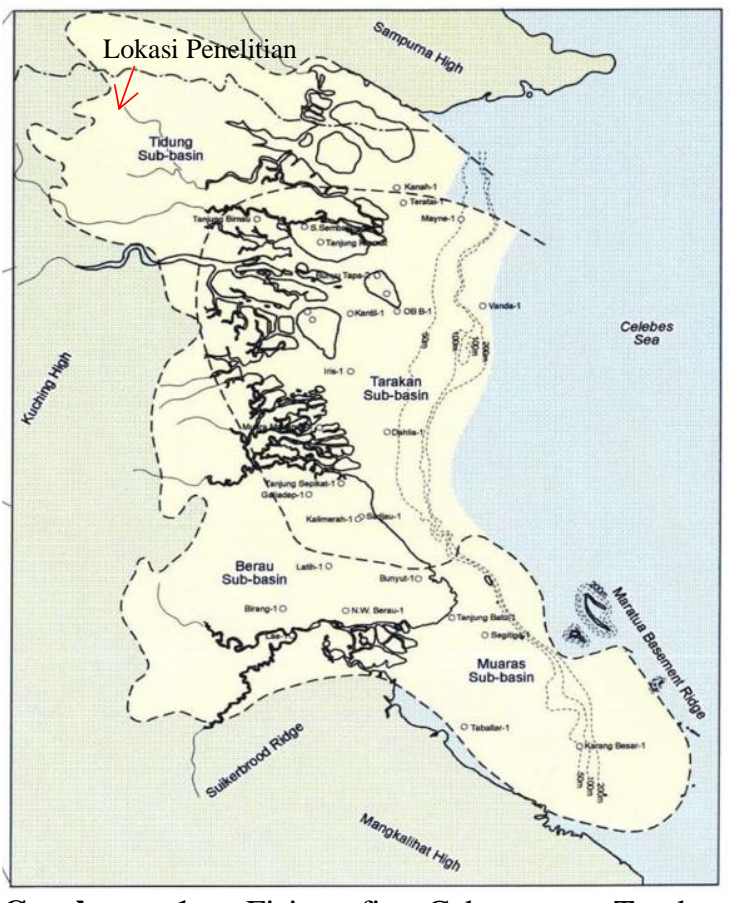

Gambar 1. Fisiografi Cekungan Tarakan (dimodifikasi dari Core-Lab $G$ and $G$ Evaluation Simenggaris Blok, dalam Sriyanto dan Ifantyana, 2016) margin Pulau Kalimantan. Dipatunggoro (2007), menjelaskan bahwa Cekungan Tarakan terbentuk pada kala Eosen hingga Pliosen.

Kabupaten Nunukan, Kalimantan Utara termasuk dalam Peta Geologi Lembar Tarakan dan Sebatik, Kalimantan dan tersusun dari delapan formasi batuan dari yang paling tua ke muda adalah Formasi Sembakung, Formasi Naintupo, Formasi Meliat, Formasi Tabul, Formasi Sinjin, Sumbat dan Retas, Formasi Sajau, dan Aluvium (Hidayat dkk., 1995). Pada penelitian ini sampel batubara yang dianalisis berada pada satu formasi batuan yang sama, yaitu Formasi Meliat. Formasi Meliat berumur Miosen Tengah dan diendapkan pada lingkungan transisi (litoral) sampai laut terbuka (inner sublittoral) yang tersusun dari batulanau, batulempung, serpih, batupasir, setempat berkembang batubara dan batugamping (Ahmad dan Samuel, 1984).

Cekungan Tarakan memiliki struktur utama berupa lipatan dan sesar yang berarah baratlaut-tenggara dan timurlaut-baratdaya, proses deformasi struktur geologi semakin meningkat ke bagian utara Cekungan Tarakan (Sriyanto dan Ifantyana, 2016). Menurut Hidayat dkk., (1995), sesar yang dijumpai pada daerah ini sebagian besar merupakan sesar normal hasil dari pengaktifan kembali sesarsesar yang sudah ada sebelumnya.

\section{Pembentukan Batubara}

Proses pembentukan batubara di mulai dari penggambutan (peatification) hingga pembatubaraan (coalification). Proses penggambutan disebut juga proses biokimia, pada proses ini terjadi perubahan kimia dan penguraian tumbuhan oleh mikroba, karena terbentuk dari akumulasi tumbuhan, maka dari itu gambut mengandung senyawa organik yang sangat tinggi, yaitu senyawa $\mathrm{C}, \mathrm{H}, \mathrm{O}$, dan $\mathrm{N}$. Proses coalification atau pembatubaraan disebut juga proses geokimia, karena dipengaruhi oleh proses geologi dan perubahan kimia.

\section{Maseral Batubara}

Maseral dibedakan menjadi tiga grup yaitu vitrinit, liptinit, dan inertinit (Stach dkk., 1982). Vitrinit adalah maseral yang terbentuk dari selulosa dan lignin yang mengandung serat kayu seperti akar, daun, dan batang. Liptinit adalah maseral yang terbentuk dari 
sisa tumbuhan dan tanaman tingkat rendah seperti ganggang, spora, kutikula, getah tanaman dan resin. Inertinit adalah maseral yang terbentuk dari tumbuhan yang sudah terbakar dan sisa oksidasi maseral lainnya.

\section{Lingkungan Pengendapan Batubara}

Terdapat dua jenis lahan gambut menurut Diessel (1992), yaitu lahan gambut ombrogen dan lahan gambut topogen. Lahan gambut ombrogen adalah lahan gambut yang dipengaruhi oleh air hujan, sedangkan lahan gambut topogen adalah lahan gambut yang dipengaruhi oleh air tanah (Gambar 2).

Martini dan Glooschenko (1984, dalam Diessel, 1992) membagi lahan gambut berdasarkan jenis tumbuhan pembentuknya menjadi empat, yaitu:

1. Bog, merupakan rawa yang banyak ditumbuhi oleh tanaman lumut atau tanaman miskin nutrisi.

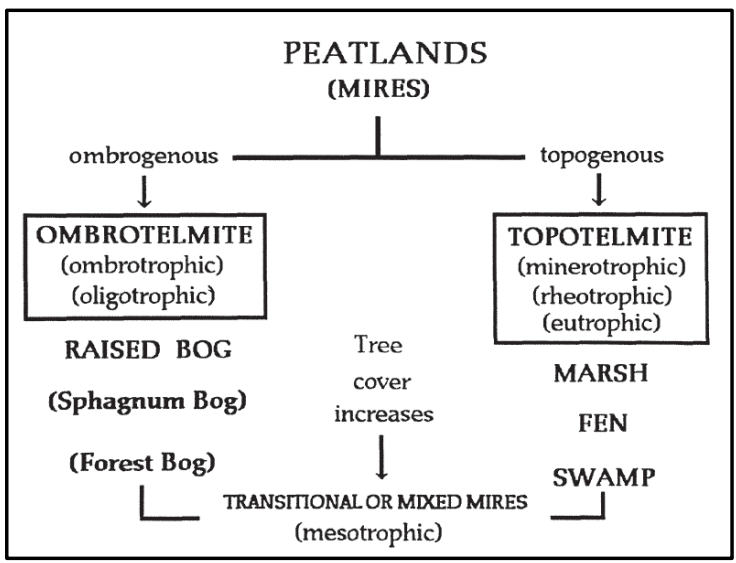

Gambar 2. Diagram lahan gambut (Diessel, 1992)
2. Fenogeni, rawa yang banyak ditumbuhi tumbuhan perdu dan beberapa jenis pohon lainnya. Lingkungan ini terkadang basah dan terkadang kering.

3. Marsh, rawa yang banyak ditumbuhi tumbuhan perdu dan jenis tanaman merambat yang umum disekitar danau atau laut.

4. Swamp, rawa yang selalu basah saat musim kemarau hingga musim dingin. Lingkungan ini kaya akan tumbuhan berkayu.

Kondisi lingkungan pengendapan batubara menurut Stach dkk., (1982) dibagi menjadi telmatis atau terestrial, limnic, marine, dan Ca-rich. Telmatis atau terestrial merupakan lingkungan yang berada di daerah pasang surut, menghasilkan gambut yang tidak terganggu dan tumbuhan tumbuh insitu ( (Gambar 3). Limnic merupakan lingkungan dimana batubara terbentuk di bawah air rawa danau. Marine merupakan lingkungan dimana batubara yang terbentuk memiliki mineral matter atau pengotor yang tinggi, seperti abu dan sulfur. Ca-rich merupakan lingkungan yang kaya akan Ca (Stach dkk., 1982).

Diessel (1992) mengklasifikasikan enam lingkungan utama terbentuknya batubara, yaitu gravelly braid plain, sandy braid plain, alluvial valley and upper delta plain, lower delta plain, backbarrier stand plain, dan estuary.

1. Braid Plain, merupakan daerah aluvial intramountana, yaitu dataran aluvial yang berada di antara pegunungan. Pada lingkungan ini terendapkan material sedimen kasar diagenesa gambut ombrogenik, yaitu gambut yang hanya ter-

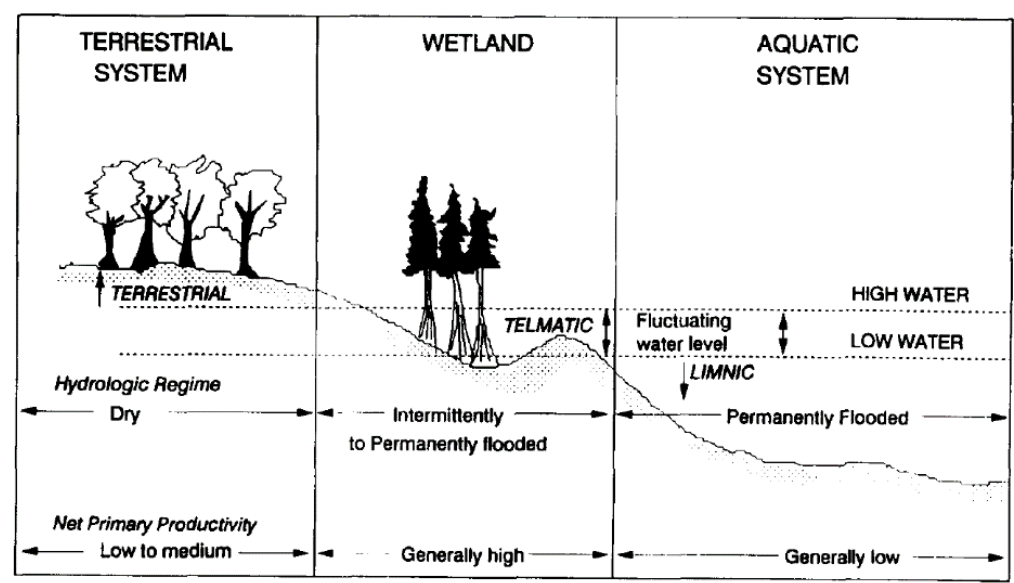

Gambar 3. Kondisi lingkungan pengendapan batubara (Mitsch dan Geosselink, 1986 dalam Lamberson dkk., 1991) 
bentuk karena pengaruh air hujan.

2. Alluvial valley and upper delta plain, kedua lingkungan pengendapan ini memiliki karaktersitik litofasies yang sama. Lingkungan terbentuk dari hasil transisi lembah dan dataran aluvial dengan dataran delta yang melalui sungai stadia dewasa dengan banyak meander. Lapisan batubara memiliki ketebalan yang bervarias dengan warna hitam kusam, komposisi abu dan sulfur terbilang lebih rendah dibandingkan dengan lingkungan pengendapan lainnya.

3. Lower delta plain, perbedaan antara lower delta plain dan upper delta plain adalah dari pengaruh pasang air laut terhadap sedimentasi. Lower delta plain memiliki pengaruh pasang surut air laut yang lebih tinggi dibandingkan upper delta plain. Pasang air laut akan membawa nutrisi kedalam rawa sehingga meningkatkan pertumbuhan yang lebih baik, namun material sedimen klastik halus ikut terendapkan di lingkungan ini yang berpengaruh terhadap kenaikan pengotor selama proses penggambutan hingga pembatubaraan.

4. Backbarrier strand plain, gambut yang terbentuk di lingkungan ini dipengaruhi oleh pasang dan surut air laut. Garis pantai dikontrol oleh tingkat sedimentasi karena gelombang, pasang surut air laut, dan arus. Delta akan terbentuk jika tingkat sedimentasi tinggi, sedangkan tingkat sedimentasi rendah, maka material sedimen akan terdistribusi sepanjang garis pantai.

5. Estuary, terbentuk karena tingkat sedimentasi dan energi pantai sangat rendah, sehingga tidak terbentuk delta. Batubara yang terbentuk dilingkungan ini sangat tipis dan persebarannya tidak luas.

Penentuan lingkungan pengendapan pada penelitian ini dilakukan dengan menggunakan diagram hubungan antara nilai GI dan TPI. TPI merupakan perbandingan antara struktur jaringan yang masih terjaga dengan struktur jaringan yang sudah terubahkan, sedangkan GI merupakan perbandingan antara komponen yang mengalami gelifikasi dengan komponen yang mengalami oksidasi (fusinification) (Diessel, 1992). Nilai TPI tinggi menunjukkan batubara berasal dari tumbuhan berkayu dan banyaknya jaringan tumbuhan yang terawetkan dengan baik. Nilai GI yang rendah menunjukkan bahwa tingkat oksidasinya tinggi, selain itu nilai GI memberikan gambaran mengenai kering atau basah kondisi pembentukan gambut karena gelifikasi berada di kondisi lembab dan sebagai indikator $\mathrm{pH}$ relatif karena aktivitas mikroba membutuhkan kondisi asam yang rendah (Diessel, 1992).

\section{Mineral Penyusun Batubara}

Menurut Stach dkk., (1982), material anorganik dapat diklasifikasikan menjadi tiga kelompok berdasarkan asalnya:

1. Mineral dari tanaman asli.

2. Mineral yang terbentuk pada tahap pertama proses pembatubaraan atau mineral yang terbawa oleh media air dan angin ke dalam akumulasi gambut selama proses pembatubaraan.

3. Mineral yang terbentuk pada tahap kedua proses pembatubaraan, setelah konsolidas, reaksi larutan yang masuk ke dalam cracks, fissures, cavities, atau akibat alterasi mineral lainnya.

Mineral yang umum dijumpai pada batubara adalah mineral lempung, sulfida, dan oksida. Mineral lempung, merupakan mineral yang paling sering dijumpai pada batubara dengan kelimpahan sekitar 60-80\% dari keseluruhan mineral matter. Mineral lempung hadir dalam batubara karena terbawa oleh media air selama proses akumulasi. Mineral lempung yang umum dijumpai adalah kaolinite, illite, dan sericite. Mineral ini terbentuk seiring dengan proses pembatubaraan, dari proses penggambutan hingga proses pembatubaraan sebagai pengisi rekahan dalam batubara.

Mineral sulfida yang paling umum terdapat di batubara adalah pirit, markasit, dan melnikovit-pirit. Pada kondisi tersebut, sebagian besar lapisan batubara mengandung sphalerite, galena, dan chalcopyrite dalam jumlah kecil (Stach, 1941; Mackowsky, 1943; Balme, 1956 dalam Stach dkk., 1982). Terdapat dua jenis pirit berdasarkan genesanya, pirit syngenetik dan pirit epigenetik. Pirit syngenetik adalah pirit yang terbentuk saat proses penggambutan, sedangkan pirit epigenetik adalah pirit yang terbentuk setelah proses pembatubaraan. Pirit terbentuk sebagai hasil reduksi sulfur primer oleh organisme dan air tanah yang mengandung ion besi, reduksi tersebut akan 


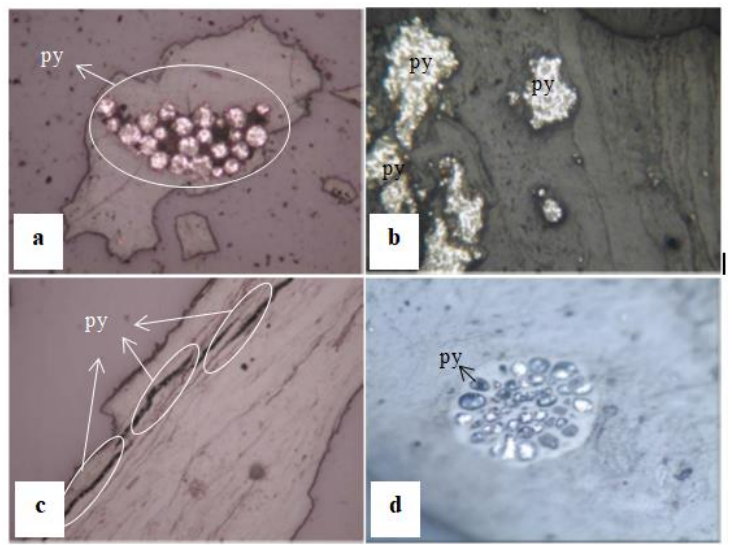

Gambar 4 Fotomikrograf mineral pirit, (a). Framboidal pyrite, (b). Massive pyrite, (c). Epigenetic pyrite, (d). Anhedral pyrite (Win, 2013)

menghasilkan pirit framboidal (Annisa, 2016). Terbentuknya pirit epigenik berkaitan dengan jumlah rekahan pada batubara, karena ion besi dalam bentuk larutan akan mengisi rekahan dan bereaksi dengan sulfur primer membentuk pirit masif. Win dkk., (2013), menjelaskan mengenai tipe-tipe pirit, tipe pirit dapat dibedakan menjadi framboidal pyrite, euhedral pyrite, massive pyrite, anhedral pyrite, dan epigenetic pyrite (Gambar 4).

1. Framboidal pyrite, beberapa penulis menjelaskan bahwa framboidal pyrite berasal dari piritisasi bakteri sulfur. Framboids adalah bentuk pirit yang umum dijumpai di lingkungan anoxic, seperti laut, lakustrin, dan rawa (Wilkin dan Barnes, 1997).

2. Euhedral pyrite, dikenal juga sebagai kristal pirit. Sebagian besar euhedral pyrite bersifat syngenetik dan dihasilkan selama pengendapan gambut atau pada awal humifikasi. Secara umum kristal pirit euhedral berukuran kecil dan tersebar di dalam batubara.

3. Massive pyrite, biasanya ditemukan sebagai cleat (kekar), cellfillings, cementing atau coating framboids dan mineral detrital. Massive pyrite juga ditemukan sebagai pengganti bahan organik dalam berbagai mineral. Massive pyrite homogen umumnya berpori dan tidak padat karena terisi oleh sisa bahan organik dan mineral lempung selama proses kristalisasi.

4. Anhedral pyrite, pirit jenis ini terbentuk dari mineralisasi sisa tumbuhan selama proses penggambutan hingga pembatubaraan, selain itu terbentuk oleh hasil ubahan dari massive pyrite.

5. Epigenetic pyrite, pirit jenis ini merupakan pirit yang mengisi cleat dan fracture.

Mineral oksida yang paling umum dijumpai adalah kuarsa, terdapat dua proses pembentukan kuarsa dalam batubara yaitu kuarsa yang terbawa oleh air atau udara (clastic quartz) dan kuarsa yang terbentuk dari larutan hasil pengendapan batubara (finelycrystalline quartz).

\section{Parameter Analisis Proksimat}

Pada penelitian ini data analisis proksimat yang digunakan adalah data ash, sulfur, dan volatile matter. Ash, merupakan material sisa pembakaran batubara berupa abu (ash) setelah batubara dibakar dengan sempurna. Material sisa pembakaran ini dapat mencerminkan mineral matter yang terkandung dalam batubara. Pada kondisi tertentu hal tersebut tidak dapat dilakukan karena akan terjadi reaksi-reaksi kimia, diantaranya adalah dekomposisi pirit, dekomposisi karbonat, dan fiksasi sulfur. Penentuan parameter ini dilakukan di laboratorium dengan membakar batubara pada suhu $750-800^{\circ} \mathrm{C}$.

Material pembentuk sulfur berasal dari material organik dan material anorganik, tidak jarang air laut juga mempengaruhi jenis sulfur yang dihasilkan. Terdapat dua jenis sulfur dalam batubara, yaitu sulfur organik dan sulfur anorganik. Sulfur organik terbentuk seiring proses penggambutan hingga pembatubaraan, berasal dari tumbuhan pembentuk batubara. Sulfur anorganik berasal dari lingkungan tempat terbentuknya batubara, mineral yang terbawa oleh air dan terakumulasi bersamaan dengan gambut, maupun larutan yang mengisi rekahan dalam batubara. Sulfur anorganik dibagi menjadi dua yaitu piritik (sulfida) sulfur dan sulfat sulfur.

\section{METODOLOGI}

Enam sampel batubara dari PT $\mathrm{X}$ dipakai di dalam penelitian ini, yaitu sampel A, B, C, D, E, dan F. Seluruh sampel dianalisis petrografi di laboratorium, sedangkan untuk data sulfur content diperoleh dari data sekunder hasil analisis proksimat. Sampel yang diinterpretasi tidak mempertimbangkan kedudukan seam tertentu atau pada jarak titik pengambilan sampel tertentu. Kenampakan fisik dari sampel 
tersebut berwarna hitam kusam, terdapat pengotor berupa sulfur pada permukaan batubara dan dapat dihancurkan atau diuraikan menggunakan tangan.

\section{Preparasi Polish Block}

Enam sampel batubara dipreparasi menjadi enam polish block. Masing-masing sampel digerus kemudian diayak dan diambil batubara yang tertahan pada ayakan ukuran 0,425 mm. Sampel yang telah digerus tersebut dituang ke dalam SamplKups, selanjutnya dituangkan campuran epoxy. Setelah mengering, dilakukan pemolesan yang dimulai dengan bubuk C180 sampai C1.200. Polish block kemuduan dimasukkan ke dalam desicator selama dua hari.

\section{Pengukuran Reflektansi Vitrinit}

Reflektansi vitrinit ditentukan oleh tingkat relatif cahaya yang dipantulkan dari permukaan sampel polished coal sesuai dengan prosedur standar yang sudah ada (Speight, 2005). Pengukuran vitrinite reflektance (Ro) adalah pengukuran terhadap besarnya sinar yang dipantulkan kembali oleh maseral vitrinite/huminite (Firdaus dkk., 2018).

Mikroskop dengan reflektor digunakan untuk melakukan pengukuran reflektansi vitrinite random (Ro) dengan perbesaran lensa objektif 50x. Mikroskop dikalibrasi menggunakan spinel 0,431 dan data dicatat dengan menggunakan CRAIC Coal Pro.

Klasifikasi menggunakan ICCP (1994, dalam Sýkorová dkk., 2005), nilai Ro<0,4\% merupakan jenis batubara coklat (brown coal) atau batubara tingkat rendah, sehingga maseral vitrinit pada batubara ini disebut sebagai huminite, sedangkan nilai Ro $>0,4 \%$ merupakan jenis batubara hitam, sehingga penyebutan maseralnya tetap yaitu vitrinit. Perbedaan nilai Ro pada setiap batubara menunjukkan bahwa intensitas pengaruh geologi berupa tekanan dan temperatur yang diterima batubara berbeda-beda. Semakin tinggi peringkat batubara maka semakin tinggi juga nilai Ro yang diperoleh. Batubara peringkat tinggi memiliki kenampakan vitrinit (mikroskopis) yang lebih terang dibandingkan dengan batubara peringkat rendah.

\section{Analisis Maseral dan Mineral Matter}

Batubara bukan zat yang homogen tetapi terdiri dari berbagai komponen dasar yang dapat dianalogikan dengan mineral dalam batuan, komponen dalam batubara disebut maseral (Langenberg dkk., 1990). Standar prosedur yang dilakukan untuk analisis maseral dan mineral matter mengacu kepada ASTM D2799-13.

\section{HASIL}

\section{Reflektansi Vitrinit}

Dari pengukuran reflektansi vitrinit keenam sampel batubara, diperoleh nilai Ro (\%random) dari sampel A hingga $\mathrm{F}$ berturutturut adalah $0,424 \%, 0,446 \%, 0,415 \%$, $0,404 \%, 0,449 \%$, dan $0,392 \%$.

\section{Maseral dan Mineral Matter}

Komposisi maseral dari enam sampel batubara yang diteliti memiliki kelimpahan yang berbeda-beda. Kelimpahan maseral telovitrinit pada batubara menunjukkan bahwa batubara tersusun oleh sel kayu dari tumbuhan yang terawetkan dengan baik sehingga tidak mengalami penghancuran (Gambar 5). Selama proses pembatubaraan, sel tumbuhan yang terawetkan selain membentuk telovitrinit akan membentuk detrovitrinit dan gelovitrinit.

Pada kelompok maseral inertinit kelimpahan lebih didominasi oleh sub-maseral detroinertinit. Detroinertinit (Gambar 6) terbentuk dari oksidasi fragmen inertinit, teloinertinit terbentuk dari oksidasi sel tumbuhan berkayu, dan geloinertinit terbentuk dari proses oksidasi humic. Pada grup maseral liptinit didominasi oleh maseral cutinite (Gambar 5) dibandingkan dengan maseral resinit, sehingga dapat diinterpretasikan bahwa jaringan tumbuhan yang terubahkan berasal dari sel kutikula tumbuhan yang lebih dominan.

Komposisi mineral matter dari yang paling dominan adalah mineral pirit, oksida besi, dan lempung (Tabel 1). Gambar 8 menunjukkan grafik antara nilai total sulfur dan mineral pirit dari setiap sampel batubara. Sampel batubara PT X memiliki komposisi sulfur tinggi, hanya satu sampel batubara yang memiliki komposisi sulfur kurang dari satu persen yaitu sampel E, sedangkan sampel yang lainnya memiliki komposisi sulfur lebih dari satu persen. 
Tabel 1. Komposisi mineral matter Mineral Matter (\%)

Sampel Lempung Pirit Oksida Besi Total

\begin{tabular}{ccccc}
\hline $\mathrm{A}$ & 1 & 2 & 1.5 & 4.5 \\
$\mathrm{~B}$ & 1 & 1.3 & 1 & 3.3 \\
$\mathrm{C}$ & 0.3 & 4.4 & 1.3 & 6 \\
$\mathrm{D}$ & 1.1 & 3.7 & 1.4 & 6.2 \\
$\mathrm{E}$ & 0.9 & 0.9 & 1.4 & 3.2 \\
$\mathrm{~F}$ & 4.4 & 6.6 & 6.6 & 17.6 \\
\hline
\end{tabular}

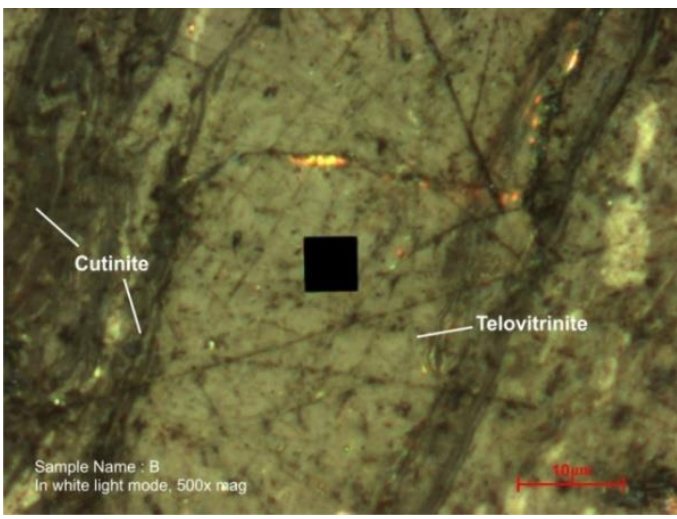

Gambar 5. Fotomikrograf sampel batubara B, submaseral telovitrinit dan maseral cutinite

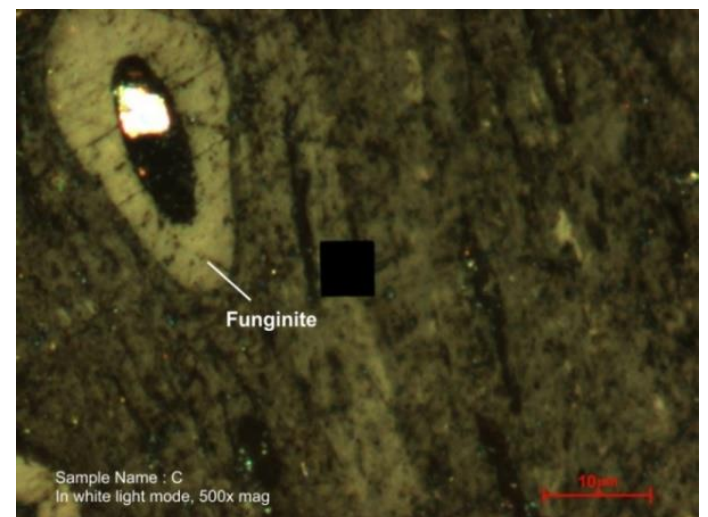

Gambar 6. Fotomikrograf sampel batubara C, submaseral teloinertinit (maseral funginite).

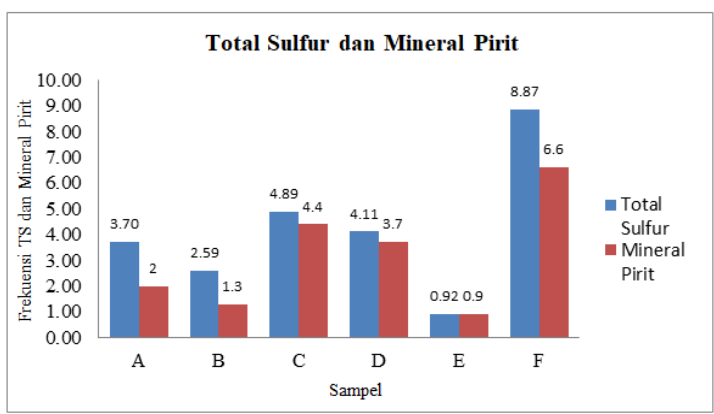

Gambar 8. Hubungan total sulfur mineral pirit.

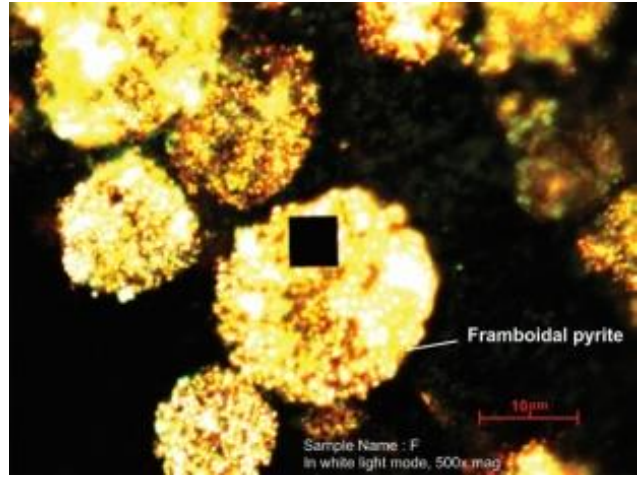

Gambar 7. Fotomikrograf framboidal pyrite pada sampel F.

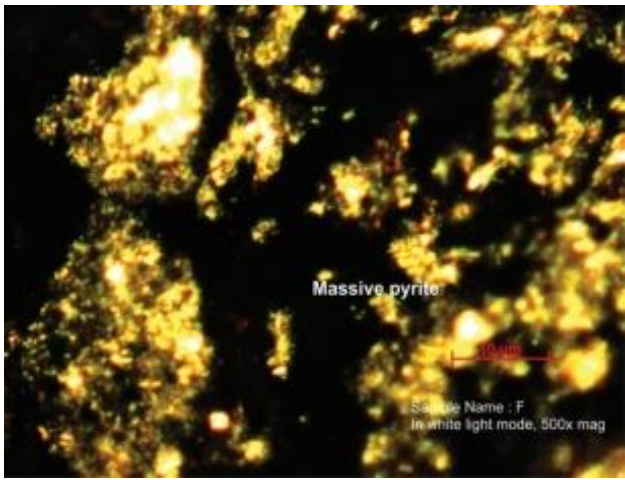

Gambar 8. Fotomikrograf massive pyrite pada sampel F.

Berdasarkan grafik hubungan total sulfur dengan mineral pirit pada Gambar 8, tampak semakin tinggi komposisi sulfur pada batubara maka akan semakin tinggi juga mineral pirit yang dihasilkan.

\section{Peringkat Batubara}

Pada penelitian ini, penentuan peringkat batubara didasarkan pada nilai volatile matter (VM) dan vitrinite reflectance (Ro) mengacu kepada Diessel (Diessel, 1992 dalam SuarezRuiz dan Ward, 2008) (Tabel 3). Batubara di daerah penelitian memiliki peringkat lignit (Tabel 2).

Tabel 2. Peringkat batubara daerah penelitian

\begin{tabular}{ccccc}
\hline $\begin{array}{c}\text { Kode } \\
\text { Sampel }\end{array}$ & $\begin{array}{c}\text { VM \% } \\
\text { (daf) }\end{array}$ & $\mathbf{R}_{\mathbf{0}} \%$ & $\mathbf{R}_{\max \%}$ & $\begin{array}{c}\text { Peringkat } \\
\text { (Diessel, } \\
\mathbf{1 9 9 2})\end{array}$ \\
\hline $\mathrm{A}$ & 49,8 & 0,424 & 0,44 & Lignit \\
$\mathrm{B}$ & 50,2 & 0,446 & 0,47 & Lignit \\
$\mathrm{C}$ & 51,8 & 0,415 & 0,43 & Lignit \\
$\mathrm{D}$ & 49,8 & 0,404 & 0,42 & Lignit \\
$\mathrm{E}$ & 46,1 & 0,449 & 0,47 & Lignit \\
$\mathrm{F}$ & 52,8 & 0,392 & 0,41 & Lignit \\
\hline
\end{tabular}


Tabel 3 Tabel peringkat batubara Diessel (1992, dalam Suarez-Ruiz dan Ward, 2008)

\begin{tabular}{|c|c|c|c|c|c|c|}
\hline \multirow[b]{3}{*}{ Rank Stage } & \multirow[b]{3}{*}{$\begin{array}{c}\% \text { Carbon } \\
(\text { daf })\end{array}$} & \multirow[b]{3}{*}{$\begin{array}{c}\% \text { Volatile } \\
\text { Matter (daf) }\end{array}$} & \multirow[b]{3}{*}{$\begin{array}{l}\text { Gross Specific } \\
\text { Energy }(\mathrm{Mj} / \mathrm{kg})\end{array}$} & \multirow[b]{3}{*}{$\begin{array}{l}\text { \% in situ } \\
\text { Moisture }\end{array}$} & \multicolumn{2}{|c|}{$\%$ Vitrinite Reflectance } \\
\hline & & & & & $\begin{array}{c}\text { (oil, } 546 \\
\mathrm{~nm})\end{array}$ & $\begin{array}{c}\text { (Diessel, } \\
\text { 1992a) }\end{array}$ \\
\hline & & & & & Rrandom & $R_{\max }$ \\
\hline Wood & 50 & $>65$ & & & & \\
\hline Peat & 60 & $>60$ & 14,7 & 75 & 0,2 & 0,2 \\
\hline Lignite & 71 & 52 & 23 & 30 & 0,4 । & $0,42 \mid$ \\
\hline Subbituminous & 80 & 40 & 33,5 & 5 & 0,6 & 0,63 \\
\hline $\begin{array}{l}\text { High volatile } \\
\text { Bituminous }\end{array}$ & 86 & 31 & 35,6 & 3 & 0,97 & 1,03 \\
\hline $\begin{array}{l}\text { Medium volatile } \\
\text { Bituminous }\end{array}$ & 90 & 22 & 36 & $<1$ & 1,47 & 1,58 \\
\hline $\begin{array}{l}\text { Low volatile } \\
\text { Bituminous }\end{array}$ & 91 & 14 & 36,4 & 1 & 1,85 & 1,97 \\
\hline Semianthracite & 92 & 8 & 36 & 1 & 2,65 & 2,83 \\
\hline Anthracite & 95 & 2 & 35,2 & 2 & 6,55 & 7 \\
\hline
\end{tabular}

- Plotting peringkat batubara

Tabel 4. Nilai TPI-GI

\begin{tabular}{ccc}
\hline Sampel & TPI (\%) & GI (\%) \\
\hline A & 3,62 & 37,92 \\
B & 1,43 & 20,68 \\
C & 0,50 & 34,77 \\
D & 1,02 & 17,73 \\
E & 0,92 & 22,25 \\
F & 0,82 & 11,90 \\
\hline
\end{tabular}

\section{PEMBAHASAN}

\section{Analisis Lingkungan Pengendapan \\ Berdasarkan Maseral}

Batubara merupakan batuan tidak homogen, tersusun dari material organik dan anorganik. Material penyusun batubara dapat memberi ciri khas dari setiap lapisan batubara,

terutama dalam penentuan lingkungan pengendapan. Data hasil analisis maseral digunakan untuk mencari nilai Tissue Preserva tion Index (TPI) dan Gelification Index (GI).

Nilai TPI dan GI (Tabel 4) kemudian diplotkan ke dalam diagram hubungan Tissue Preservation Index (TPI) dan Gelification Index (GI) untuk memperoleh lingkungan pengendapan batubara (Gambar 9).

Berdasarkan diagram TPI dan GI (Gambar 9), sampel batubara PT X terendapkan di lahan gambut swamp dan marsh. Lahan gambut tersebut termasuk dalam golongan lahan gambut topogen. Lahan gambut topogen terbentuk di lingkungan yang lebih dikontrol oleh air tanah dibandingkan dengan air hujan. Lahan gambut topogen juga dipengaruhi oleh air pasang, oleh sebab itu lahan gambut topogen kaya akan unsur hara dan nutrisi, serta tanahnya lebih subur dibandingkan dengan lahan gambut ombrogen. Pengkayaan nutrisi pada lahan gambut ini dibuktikan dengan jenis tumbuhan yang dominan tumbuh adalah jenis tumbuhan tingkat tinggi, seperti tumbuhan berkayu ataupun tumbuhan perdu dibandingkan dengan tumbuhan lumut atau tumbuhan tingkat rendah yang umum dijumpai di lahan gambut ombrogen.

\section{Lingkungan Pengendapan Batubara PT X}

Diessel (1986, dalam Suwarna, 2006), menjelaskan bahwa nilai TPI tinggi apabila memiliki nilai $>1 \%$ dan nilai GI tinggi apabila memiliki nilai $>5 \%$. Pada perhitungan TPI dan GI sampel batubara di PT X, menunjukkan nilai TPI berkisar $0,5 \%$ hingga $3,62 \%$, diasumsikan nilai tersebut tergolong rendah hingga tinggi. Pada sampel batubara A menunjukkan nilai TPI paling tinggi yaitu $3,62 \%$, diinterpretasikan pada saat proses terbentuknya sampel batubara A terjadi proses penurunan permukaan tanah yang cepat karena tingginya proses sedimentasi sehingga maseral batubara terhindar dari proses penghancuran dan terawetkan dengan baik, sedangkan untuk sampel batubara B hingga $F$ diasumsikan nilai tersebut tergolong rendah hingga menengah. 


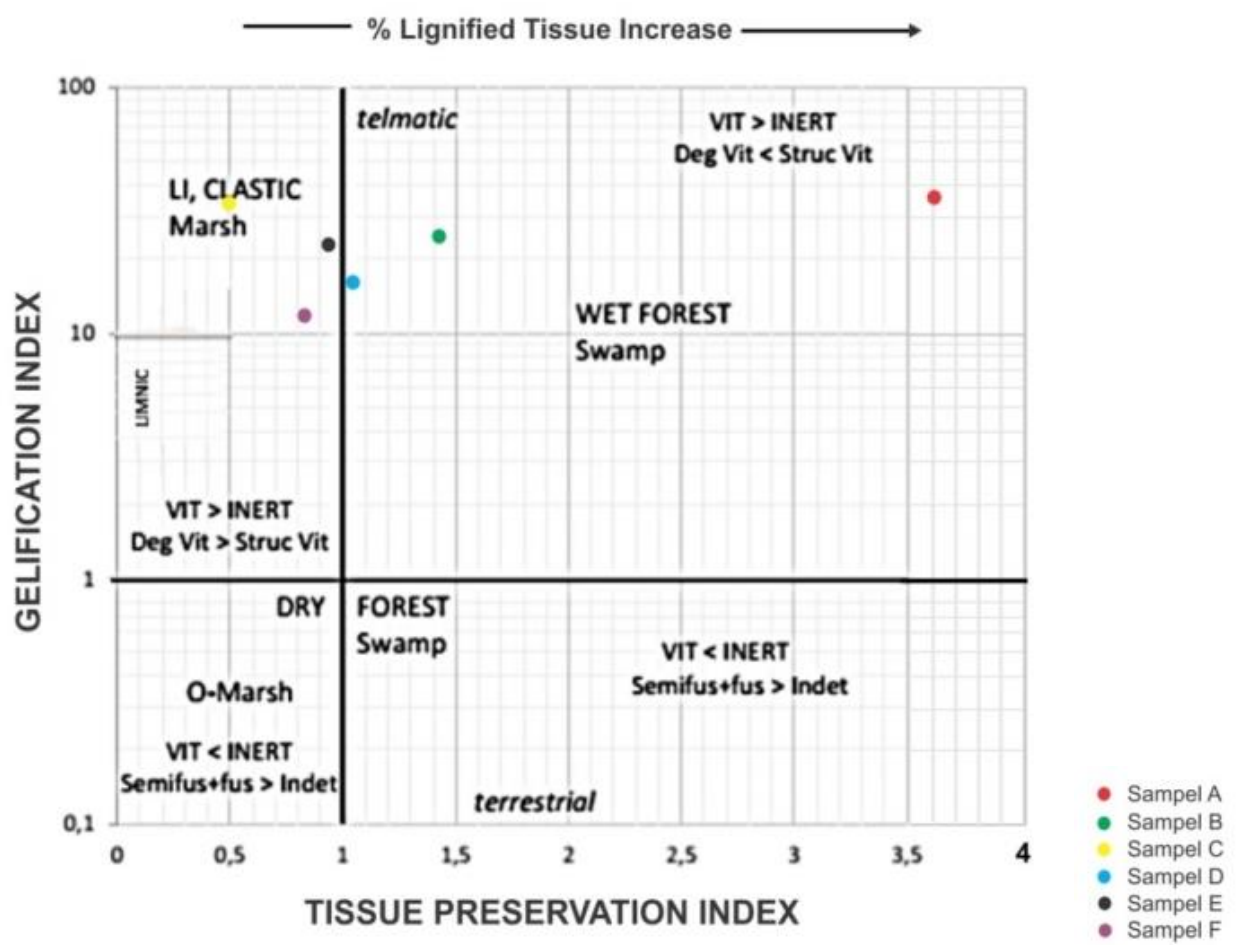

Gambar 9. Hasil plotting pada diagram TPI-GI (dimodifikasi dari Diessel, 1986, dalam Lamberson, 1991).

Diinterpretasikan bahwa kondisi lingkungan sampel batubara $\mathrm{B}$ hingga $\mathrm{F}$ mengalami proses penurunan permukaan tanah dan proses sedimentasi yang lebih lambat dibandingkan dengan kondisi lingkungan sampel batubara A. Nilai GI dari keenam sampel batubara yang diteliti memiliki nilai berkisar $11,90 \%$ hingga $37,92 \%$, diasumsikan nilai tersebut tergolong tinggi.

Pada sampel batubara E, komposisi pirit dan sulfur memiliki nilai paling rendah dibandingkan dengan sampel batubara lainnya. Hal tersebut diinterpretasikan bahwa selama proses akumulasi gambut, pengaruh pasang air laut tidak terlalu intensif dibandingkan dengan kondisi lingkungan sampel batubara yang lainnya. Berdasarkan klasifikasi lingkungan pengendapan yang telah dijelaskan oleh Diessel (1992) dan merujuk pada nilai TPI-GI, nilai sulfur, dan kenampakan megaskopis batubara, menunjukkan bahwa sampel batubara PT X terendapkan di lingkungan lower delta plain. Lingkungan lower delta plain merupakan lingkungan yang dipengaruhi oleh pasang surut air laut.

Pada Tabel 1 ditunjukkan bahwa komposisi mineral pirit dari batubara di daerah penelitian berkisar antara 0,9-4,4\%. Berdasarkan pengamatan petrografi, dijumpai dua jenis mineral pirit yaitu framboidal pyrite (Gambar 7a) dan massive pyrite (Gambar 7b). Menurut Falcon dan Snyman (1986, dalam Win dkk., 2013), akumulasi pirit dalam batubara dihasilkan dari import fluviatile yang membawa mineral kaya akan besi pada saat akumulasi gambut diikuti oleh presipitasi insitu. Pirit framboidal terbentuk pada daerah penelitian karena mendapat pengaruh dari laut (Wilkin dan Barnes, 1997), didukung dengan geologi regional yang menyebutkan bahwa formasi pembawa batubara di daerah penelitian, yaitu Formasi Meliat, diendapkan pada lingkungan transisi (Ahmad dan Samuel, 1984).

\section{KESIMPULAN}

Berdasarkan hasil penelitian, diketahui bahwa batubara terendapkan di lahan gambut wet forest swamp dan clastic marsh serta pada kondisi lingkungan telmatic dan limnotelmatic. Nilai TPI pada sampel batubara yang tergolong rendah hingga tinggi dan nilai GI yang tinggi, membuktikan bahwa sampel batubara yang diteliti terendapkan di lingkungan lower delta plain. Kandungan sulfur yang tinggi pada batubara serta kehadiran pirit framboidal disebabkan pengaruh air laut pada saat pembatubaraan. 


\section{UCAPAN TERIMA KASIH}

Penulis menyampaikan terima kasih kepada PT SUCOFINDO (Persero) Cabang Balikpapan yang bersedia menyediakan fasilitas untuk keperluan analisis data petrografi batubara.

\section{DAFTAR PUSTAKA}

Diessel, C.F.K, 1992, Coal-Bearing Depositional Systems. Springer-Verlag, Berlin Heidelberg.

Dipatunggoro, G., 2007, Low Rank Coal Formasi Sajau Daerah Teluk Semanting dan Tanjung Batu Kecamatan Pulau Derawan, Kabupaten Berau - Kalimantan Timur, Buletin of Scientific Contribution 5(2), 83-93.

Firdaus, N., Syafri, I., Mohammad, R., dan Suwarna, N., 2018, Analisis Komposisi Maseral dan Mineral dengan Metode Reflectance Huminite untuk Mengetahui Kematangan Kerogen Batubara Cekungan Bentarsari, Kabupaten Brebes, Provinsi Jawa Tengah, Padjadjaran Geoscience Journal, 2(6), 498-507.

Hidayat, S., Amiruddin, dan Satrianas, D., 1995, Geologi Lembar Tarakan dan Sebatik, Kalimantan Skala, Irwan Bahar (Director), Pusat Penelitian dan Pengembangan Geologi, Skala 1:250.000.

Lamberson, M.N., Bustin, R.M dan Kalkreuth, W., 1991, Lithotype (maceral) composition and variation as correlated with paleowetland environments, Gates Formation, northeastern British Columbia, Canada, International Journal of Coal Geology, 18, $87-124$.

Langenberg, W., Wolfgang, Kalkreuth., Jeffrey, L., Rudy, S., Thomas, D., Georgia, R., dan Tomasz, J., 1990, Coal Geology And Its Application To Coal-Bed Methane Reservoirs, Alberta Research Council.

Said, N, I, 2014, Teknologi Pengolahan Air Asam Tambang Batubara "Alternatif Pemilihan Teknologi”, JAI, 7(2).

Speight, G, J, 2005, Handbook of Coal Analysis, Wiley-Interscience, Vol, 166. Canada

Sriyanto, S. P. D., dan Ifantyana, I, 2016, Identifikasi Patahan Mikro Penyebab Gempa Bumi Tarakan 21 Desember 2015, Prosiding Seminar Nasional Fisika, Vol, V, DOI: doi.org/10.21009/0305020415.
Stach, E., M,-TH, Mackowsky., M, Teichmuller., G, H, Taylor., D, Chandra., dan R, Teichmuller, 1982, Coal Petrology, Berlin: Gebrüder Borntraeger.

Suarez-Ruiz, I., dan Colin, R, W, 2008, Applied Coal Petrology, Elsevier.

Sukandarrumidi, 1995, Batubara dan Gambut, Yogyakarta: Gadjah Mada University Press.

Susilawati, R, 2018, Rekonsiliasi Data, Sumber Daya Batubara Indonesia Kini 166 Miliar Ton, Cadangan 37 Miliar Ton, Kementerian Energi dan Sumber Daya Mineral Republik Indonesia, Bidang Batubara PSDMBP.

Suwarna, N., 2006, Permian Mengkarang Coal Facies and Environment, Based on Organic Petrology Study, Jurnal Geologi Indonesia, 1(1), 1-8.

Sýkorová, I., Pickel, W., Christanis, K., Wolf, M., Taylor, G, H., dan Flores, D., 2005, Classification of huminie-ICCP System 1994, International Journal of Coal Geology, 62, 85 - 106, Elsevier.

Thomas, Larry, 2013, Coal Geology Second Edition, Wiley-Blackwell, Page. 3

Triono, U., 2005. Inventarisasi Batubara Marginal di Daerah Simenggaris Kabupaten Nunukan Provinsi Kalimantan Timur. Pemaparan Hasil Kegiatan Lapangan Subdit Batubara. Departemen Energi dan Sumberdaya Mineral.

Wibisono, S, A., dan Wawang S, P., 2015, Penyelidikan Batubara di Daerah Nunukan Timur Kabupaten Nunukan, Provinsi Kalimantan Utara, Kementerian Energi dan Sumber Daya Mineral: Badan Geologi.

Wilkin, R, T., dan Barnes, H, L, 1997, Formation Processes of Framboidal Pyrite, Geochimica et Cosmochimica Acta, 61(2), 323 - 339, Elsevier Science Ltd.

Win, C, T., Surjono, S, S., Amijaya, D, H., Husein, S., Aihara, A., dan Watanabe, K., 2013, Distribution of Pyrite and Mineral Matter in Coal Seams from Samarinda Area, Lower Kutai Basin, Indonesia. ASEAN Forum on Clean Coal Technology. The $11^{\text {th }}$ International Conference on Mining, Materials and Petroleum Engineering and The $7^{\text {th }}$ International Conference on Earth Resources Technology. 